\title{
STATE PLANS UNDER THE OCCUPATIONAL SAFETY AND HEALTH ACT OF 1970
}

\author{
BARRY BROWN* \\ INTRODUCTION
}

Section 18 of the Occupational Safety and Health Act of 1970 provides that nothing in the Act shall prevent any state agency or court from asserting jurisdiction over occupational safety or health where no standard is in effect under the federal law. ${ }^{1}$ In addition, a state may reassume responsibility for occupational safety and health where federal standards are applicable by submitting a comprehensive plan for the development and enforcement of its own standards. ${ }^{2}$ This plan will be approved by the Secretary of Labor if it meets a series of requirements designed to assure that the state plan is or will be as effective as the federal program. ${ }^{3}$ In spite of some protestations to the contrary, ${ }^{4}$ section 18 thus makes it clear that Congress intended the states to have a major, if not an exclusive, role in job safety and health matters.

But why would Congress return authority to the states regarding occupational safety and health? Everyone connected with promoting the 1970 legislation agrees that it was the failure of the great majority of states to adequately protect working men and women that created the need for the federal government to act in the first place..$^{5}$ If that was the case, why would Congress clearly seek to maintain a predominant role for the states in this program? The failure of all past federal programs for job safety must have played a major part in the decision. For some Congressmen, the question of states' rights was also significant. Those

*Sommers, Schwartz, Silver, Schwartz, Tyler \& Gordon, Southfield, Michigan; formerly Director, Michigan Department of Labor (1969-74).

1 Occ. Safety \& Health Act § 18(a), 29 U.S.C. § 667(a) (1970).

2 Id. § 18(b), 29 U.S.C. $\$ 667(\mathrm{~b})$.

${ }^{3}$ Id. $\$ 18$ (c), 29 U.S.C. $\$ 667$ (c). See also 29 C.F.R. \& 1902 (1973). Mr. John J. Sheehan, Legislative Director, United States Steelworkers of America, would interpret this language to mean only that a state with an approved plan must "evolve in effectiveness consonant with future growth in the federal program." Hearings Before the Select Subcomm. on Labor of the House Comm. on Educ. and Labor, 93d Cong., 2d Sess. (May 23, 1974). This interpretation not only misconstrues explicit statutory language, but is contrary to the obvious congressional intent to allow states to improve upon their programs as they existed at the time the Act was passed. The grant provisions of section 23 also support the concept of initial developmental plans. Occ. Safety \& Health Act $\S 23,29$ U.S.C. § 672 (1970). In addition, the Secretary's regulations carry out this congressional intent in that they provide for the development and continuation of a state's "at least as effective as" program. 29 C.F.R. $\$ \S 1902,1952-54$ (1973). An interpretation such as Mr. Sheehan's would have completely foreclosed any states from participating in state plans-a result which was clearly not intended by Congress.

${ }^{4}$ See Brief for Plaintiff at 5, AFL-CIO v. Brennan, Civil No. 74-406 (D.D.C., filed March 11, 1974). See also Remarks by John J. Sheehan, Legislative Director, United States Steelworkers of America, in Hearings Before the Select Subcomm. on Labor of the House Comm. on Educ. and Labor, 93d Cong., 2d Sess. (May 23, 1974).

'See, e.g., Subcomm. on Labor of the Senate Comm. on Labor and Public Welfare, 92d Cong., lst Sess., Legislative History of the Occupational Safety and Health Act of 1970, at 144 (Comm. Print 1971). 
members believed that the closer any government function was to the people it serves, the better that form of government. For other Congressmen, it was a question of manpower. ${ }^{6}$ It was certain when the law was passed in 1970 that it would be some time before the U. S. Department of Labor could hire replacements or transfer the nearly 2,000 state inspectors that were in the field. Congress simply was not prepared to disenfranchise all of these individuals without a clear plan by the federal government for replacing them. The opponents of any state programs have stated that if the activities of these state inspectors were terminated, the federal Department of Labor would be forced to hire replacements or to accept the transfer of displaced state inspectors. ${ }^{7}$ This naive proposal ignores the congressional track record on prior federal safety programs. It also is blind to the niggardly personnel commitments thus far established for both the Occupational Safety and Health Administration (OSHA) and the National Institute of Occupational Safety and Health (NIOSH). ${ }^{8}$ Finally, there was the question of cost. Congress desired neither that the states, especially the large industrial states, discontinue spending millions of dollars on job safety and health nor that federal funds replace those state expenditures.

\section{Critics and Advocates of State Jurisdiction}

The question of whether state agencies should be the sole or primary governmental unit charged with the promulgation of standards and their enforcement under the Act evokes extremely varied responses from differing interest groups. Ralph Nader, environmentalists, and other "public interest" organizations would say that states could not be trusted to administer such a program. These spokesmen are suspicious of state government and maintain that all programs designed to achieve social change are best administered by a strong central government. They believe that state administrators are parochial and that state legislatures are archaic. The governors, on the other hand, believe the states should do the job. In fact, only five governors have yet to submit a proposal for state takeover of responsibility under the Act ${ }^{9}$-and there is some indication that even these states may participate in the OSHA program in the future. ${ }^{10}$

The U. S. Department of Labor, through its Secretary and its Assistant Secretary in charge of occupational safety and health, has been a strong supporter of state programs. While it is clear that this is top-level policy within the Department, there are some career employees at the lower levels who demonstrate

\footnotetext{
${ }_{6}$ See id. at 159, 161, 861-62.

${ }^{7}$ See Statement by John J. Sheehan, Legislative Director, United States Steelworkers of America, before a Subcomm. on State Programs of the National Advisory Committee for Occupational Safety and Health (NACOSH), in Official Report of Proceedings 43-44 (Sept. 23, 1972).

${ }^{8}$ See, e.g., President's Budget Request for Fiscal 1974 (1973), wherein authorization for only 800 OSHA compliance officers for the entire country was sought.

The following jurisdictions have not submitted plans: Kansas, Louisiana, Nebraska, Ohio, and South Dakota. 3 Occ. Safety \& Health ReP. 848-49 (1973).

${ }^{10}$ See id. Four states-Georgia, New Hampshire, North Dakota, and Pennsylvania-have withdrawn previously submitted state plans. However, substantial support for state plans remains in Georgia, North Dakota, and Pennsylvania. Id.
} 
a lack of enthusiasm for state programs. Nevertheless, the official federal position continues to be encouragement for effective state programs in spite of strong and persistent criticism. ${ }^{11}$ In addition, the'business community across the United States appears to favor state plans, though there has been a cooling of enthusiasm in large interstate firms in recent months. Some steel and chemical firms and a few of the larger international building contractors have voiced outright opposition to state plans. However, smaller firms, intrastate operations, local chambers of commerce, and business in general still support administration by state governments.

Many-unions oppose state plans. ${ }^{12}$ They fear that the state government will be soft toward business because strict local enforcement could result in closures and loss of jobs within the state. They believe they have a much better chance of gaining their goals for true safety and health on the job through Congress and the U. S. Department of Labor than they do in the fifty states. While the international unions and their Washington lobbyists have been unswerving in their opposition to state plans, local union leaders and state labor councils have passively and at times actively supported effective state plans, sometimes even aiding legislative efforts to pass such plans in state legislatures. ${ }^{13}$

\section{II}

\section{Criticisms of State Plans}

The critics of state safety programs and the federal Department of Labor's encouragement of state plans under the Act allege that the states have never done a good job in safety, that state standards are inadequate, that state inspectors are unqualified and too few in number, and that state safety programs are dominated by management. ${ }^{14}$ Further, it is said that the states have been granted too much leeway under the guidelines and indices of effectiveness promulgated by the U. S. Department of Labor. It is feared that these "loose" guidelines will erode the Occupational Safety and Health Act and that the hard-won gains in the U. S. Congress will be lost under weak state programs. It is also asserted that encouragement of the states to submit and operate under "development plans"15 has allowed them to receive federal funds and to retain authority to enforce standards before reaching levels of effectiveness actually equivalent to those of the federal program. The critics declare that plans should not have been approved in this way because the states are tendering only "paper promises"

${ }^{11}$ See Address by John Stender, Assistant Secretary of Labor, before the Montana State Legislature, Jan. 17, 1974, in id. at 1034-35.

${ }_{12}$ Remarks by I.W. Abel, President, United States Steelworkers of America, Frank E. Fitzsimmons, President, Teamsters Union, Floyd E. Smith, President, International Association of Machinists and Aerospace. Workers, March 15, 1973, in 2 id. at 1183-84. See also Industrial Union Dep't, AFL-CIO, Coalition Position Against New York Program: Spotlight on Health and Safety (1st Quarter 1974).

${ }^{13}$ See 3 Occ. Safety \& Health Rep. 849 (1973). Compare Michigan with Pennsylvania.

${ }^{14}$ See Statement by George Taylor, Industrial Union Department, AFL-CIO, Member, National Advisory Committee for Occupational Safety and Health, before a Subcomm. on State Programs of NACOSH, in OfFicial Report of Proceedings 56-80 (Mar. 15, 1973).

${ }^{15}$ See 29 C.F.R. § 1902.2(b) (1973). 
for needed legislation, staffing, and standards. ${ }^{16}$ Finally, it is said, state plans should not be encouraged because a state legislature can always refuse to appropriate money and thus scuttle the program for that state. They could also earmark money or "line item" appropriations in a way that would frustrate the goals and objectives of the Act. ${ }^{17}$

While the foregoing list of charges against state programs is not exhaustive, it is representative and each claim should be examined. It is true that the states have not done a good job in safety, but the federal government has not performed as well as many states. How can anyone advocate the federal government as the sole cure-all in the field of job safety when the best it has done for years is to equal many states in poor performance? For example, the federal government has had the reponsibility for safety in longshoring for more than a dozen years. ${ }^{18}$ Though there has been steady, slow improvement in the safety record of this industry, it continues to be one of the highest hazard occupations in our country. ${ }^{19}$ Moreover, within the federal government there are a number of departments with accident records worse than those found in private industry. ${ }^{20}$ This poor federal record in safety has been created and perpetuated under both Democratic and Republican administrations, so it has no particular partisan sponsorship.

The charge that state standards are inadequate is ridiculous in light of the fact that the bulk of the federal standards are "national consensus standards"21 which have been adopted pursuant to section 6(a) of the Act. ${ }^{22}$ Many, if not most, of the states have adopted verbatim or utilized national consensus standards as sources for their own standards. Indeed, OSHA has often been criticized for the application of its standards because of the confusion it has caused. OSHA has also been rebuffed by the courts when it has attempted to modify its standards $^{23}$ or create new ones. ${ }^{24}$

There is simply no solid evidence to support a charge that state standards have been inadequate, especially when one compares OSHA's track record in the standards arena. Admittedly, some state programs in the past have not included all of the hazards covered by OSHA standards. But not even the state

${ }^{16}$ See note 14 supra.

${ }^{17} I d$.

${ }^{18}$ Longshoremen's and Harbor Workers' Compensation Act $\$ 41,33$ U.S.C. $\S 941$ (1970), formerly ch. 509, § 41, 44 Stat. 1444 (1927). Section 941 of the Act was passed in 1958, Pub. L. No. 85-742, 72 Stat. 835 (1958).

19 U.S. Bureau of Labor Statistics, Dep't of Labor, Final Estimates of Job-Related INJURIES AND ILLNESSES IN 1972 (1974).

${ }^{20}$ Hearings on H.R. 843, H.R. 3809, H.R. 4294, H.R. 13373, Before the Select Subcomm. on Labor of the House Comm. on Educ. and Labor, 91st Cong., lst Sess., pt. 1, at 363 (1969).

${ }^{21}$ See Occ. Safety \& Health Act \& 3(9), 29 U.S.C. \$ 652(9) (1970).

${ }^{22}$ Section 6(a) of the Act authorized the Secretary to promulgate by merely publication in the Federal Register, "national consensus standards" for a period of up to two years of the effective date of the Act. Id. $\$ 6(\mathrm{a}), 29$ U.S.C. $\$ 655(\mathrm{a})$. The first sets of such national consensus standards were promulgated by the Secretary and published in the Federal Register on October 18, 1972. See 37 Fed. Reg. 22,102-356 (1972).

${ }^{23}$ See Associated Indus. v. United States Dep't of Labor, 487 F.2d 342 (2d Cir. 1973), which vacated the Secretary's modified sanitation standard.

24 See Florida Peach Growers Ass'n v. United States Dep't of Labor, 489 F.2d 120 (5th Cir. 1974), wherein the court stayed the effect of the Secretary's emergency temporary pesticides standard. 
plan provisions of the Act require states to cover all hazards. ${ }^{25}$ States are free to choose which hazards they wish to cover; when a state decides not to occupy a particular area, federal standards continue to apply, despite the existence of a state plan. ${ }^{26}$

Another charge that cannot be substantiated is that state inspectors are incompetent or uniformly management oriented. The fact is that labor departments in large industrial states are filled with highly qualified personnel guided by both Republican and Democratic administrations. The pay for state occupational safety personnel in New York and California is often higher than corresponding federal compensation. Federal studies have shown state health inspectors have job entrance requirements comparable to their federal counterparts. ${ }^{27}$

National union leaders have recently charged that the federal guidelines for state plans allow the states too much leeway, thus jeopardizing the hard-won gains of organized labor. ${ }^{28}$ The Occupational Safety and Health Act of 1970 was clearly a compromise for which many Congressmen would not have voted without the provisions that encourage and strengthen state participation in safety programs. ${ }^{29}$ Many state labor commissioners believe that national labor leaders are defaulting on that compromise by their across-the-board opposition to state plans. It seems that they are trying to achieve administratively what they could not achieve in the legislature. If Congress had wanted every state plan to duplicate the applicable federal provisions, it could easily have said so. Instead, Congress provided a list of eight major points that must be met by a state in order for it to gain plan approval. ${ }^{30}$ Thus, it can be effectively argued that any "leeway" allowed by federal guidelines properly implements federal intent, since the federal regulations require inclusion of the eight points, and more. ${ }^{31}$

Another major point of critics is that states should not be allowed to operate under "developmental" plans because they are filled with "paper promises."32 Any government plan in its inception is a "paper promise," including the federal plans for OSHA and NIOSH. If a state plan were not approved under section 18(b) until state legislation, standards, procedures, and personnel were all up to the final levels contemplated for OSHA, then we would have no state plans yet approved. With the federal government so far from its own internal targets, it seems blatantly inconsistent of the critics of state plans to charge states with failing to meet a theoretical goal of what should be when the law requires only that a state propose a plan that is or will be as effective as the federal program. It seems equally inconsistent for the critics to speak of federal inadequacies in one breath and then to clamor for exclusive federal jurisdiction in the next. ${ }^{33}$

\footnotetext{
${ }^{25}$ Occ. Safety \& Health Act $\S 18(b), 29$ U.S.C. $\S 667$ (b) (1970). See also 29 C.F.R. § 1902.2(c) (1973).

${ }^{27}$ See Comments by Richard Wilson, Deputy Director, State and Federal Programs, before NACOSH, in Transcript of Official Proceedings (Dec. 6, 1973).

${ }^{28}$ See note 4 supra.

${ }^{29}$ See Address by John Stender, supra note 11.

${ }^{30}$ See Occ. Safety \& Health Act §§ 18(c)(1)-(8), 29 U.S.C. $\S \S 667(c)(1)-(8)$ (1970). See also 29 C.F.R. $\S \S 1901,1902,1952.1-.8$ (1970); 38 Fed. Reg. 24,361-64 (1973); 39 Fed. Reg. 1837-39 (1974)

${ }^{31}$ See 29 C.F.R. \$ 1902 (1973).

32 See notes 4 \& 14 supra.

${ }^{33}$ See note 4 supra.
} 
Finally, the critics have pointed out that state legislatures could refuse to appropriate money for state safety programs. This is absolutely true, but Congress could also refuse to appropriate money for federal safety programs. Indeed, Congress has in very recent years demonstrated its unwillingness to appropriate adequate funds for safety programs. In 1972, the labor movement was able to secure an additional $\$ 10$ million from the Senate for the U. S. Department of Labor's OSHA program, only to have the House of Representatives greatly reduce the appropriation..$^{34}$ That action clearly refutes any argument that federal appropriations for OSHA are certain and state funding doubtful.

If the approximately $\$ 200$ million now expended by the states is enlarged to anticipate the higher outlays necessary under the Act and then added to (1) the money that will always be necessary for a separate federal administration in those states that will not have an occupational safety and health program and (2) the federal monitoring costs required when a state does retain safety responsibility, the hugh outlay of funds necessary under the administration's current policies can be seen. Then it must be obvious that state monetary participation is necessary in order to maintain the existing level of the overall occupational safety and health program effort. If the states that are already effective in occupational safety are encouraged to continue their participation, the federal obligation in these jurisdictions is, in effect, reduced by half. Existing administration policy allows participating states to retain their compliance officers, their safety training staff, the office administrators, and the technicians that are currently employed. These are the very types of personnel the federal agency is finding difficult to recruit or retain. Present policy thus also eliminates the three or four years the federal government would need (assuming congressional support) to gear up to existing levels of state performance in these areas. Any hiatus in the enforcement effort would be a high price to pay to satisfy Washington-based lobbyists willing to buy centralization at any cost.

III

The Positive Side of State Plans

Initially, all but three of the states-New Mexico, Ohio, and South Dakota-participated under section $18(\mathrm{~h})$ of the Act, ${ }^{35}$ continuing to enforce their laws concurrently with the federal government in 1971 and 1972 . By mid1974, state plans had been approved for twenty-five jurisdictions: Alaska, California, Colorado, Connecticut, Hawaii, Illinois, Indiana, Iowa, Kentucky, Maryland, Michigan, Minnesota, Nevada, New Jersey, New York, North Carolina, Oregon, South Carolina, Tennessee, Utah, Vermont, Virgin Islands, Washington, Wisconsin, and Wyoming. Six jurisdictions have never formally submitted requests

${ }^{34} 118$ Cong. Rec. H 7080-81 (daily ed. Aug. 2, 1972).

${ }^{35}$ Under section $18(\mathrm{~h})$ of the Act, states were permitted to enter into agreements with the federal government which allowed them to continue enforcement activities pending the Secretary of Labor's decision on the states' developmental plan. The statutory authority for such agreements expired on December 29, 1972. Thus, if the Secretary took no action within two years of the date of enactment to approve a plan, the state's law was preempted. Occ. Safety \&c Health Act § 18 (h), 29 U.S.C. $\S 667$ (h) (1970). See note 39 infra. 
for approval: Kansas, Louisiana, Nebraska, Ohio, South Dakota, and the trust territories. Five states-Georgia, Montana, New Hampshire, North Dakota, and Pennsylvania-originally submitted plans but have subsequently withdrawn them. Hence, twenty plans are still under consideration, including those of several states, territories, the District of Columbia, and Puerto Rico. ${ }^{36}$ These plans are pending before the Assistant Secretary of Labor, awaiting his determination as to whether they meet the test of section 18 of the Act and his regulations. ${ }^{37}$

\section{A. The Washington State Plan}

In the State of Washington, the state legislature displayed unusual bipartisan responsibility and unanimously gave its state department of labor a complete mandate to proceed with administration of a state law that is, in the eyes of many, more effective than the federal law. Washington has achieved such a degree of development in enforcement in the less than two years that have passed since achieving OSHA approval that some of the federal employees of that state have been reassigned to other states, where there is no comparable state activity. The only compliance complaints now handled by the federal personnel in the State of Washington are those concerning the state's administration of the program. The workplaces of more than two-thirds of the state's employees have been inspected in one year. More than 15,000 inspections discovered more than 48,000 violations and resulted in nearly $\$ 132,000$ in fines. Washington was able to achieve this high level of job safety and health administration so promptly because it had 60 years of experience, a staff of 113 , a budget of $\$ 1.5$ million, a sophisticated law on the books, and a good working relationship with management and labor in the state.

\section{B. The Iowa State Plan}

There was a very small-scale job safety and health program in Iowa before 1970. In 1971, the state government worked closely with a state college in developing its plan, submitting it early in the summer of 1972. The Iowa legislature promptly passed legislation that apparently met the criteria of the federal guidelines. However, it was different from the federal Act in some respects and OSHA questioned the wisdom of some of the variations. ${ }^{38}$ Prior to federal approval, Iowa had hired new inspectors who were already out enforcing the new, stronger state laws and assessing fines when appropriate. Their enforcement efforts were suspended in 1972, when a federal court ruled that the provision of the federal Act which permitted two years of joint federal and state enforcement could not be administratively extended. ${ }^{39}$ It was not until June of 1973

\footnotetext{
${ }^{36}$ Data supplied by the Office of Federal and State Operations, OSHA, update as of June, 1974 (on file with the author).

${ }_{37}$ Occ. Safety \& Health Act $\$ 18,29$ U.S.C. § 667 (1970). See also 29 C.F.R. $\S 1902$ (1973).

38 CCC Employment Safety \& Health Guide $\$ 8856$.

${ }^{39}$ See Industrial Union Dep't, AFL-CIO v. Hodgson, 2 Occ. SafETy \& Health REP. 867 (D.D.C., Jan. 2, 1973) (order granting preliminary injunction against enforcement of extension). The Secretary had attempted to extend the life of section 18(h) by regulation, 37 Fed. Reg. 25,711-12 (1972), which was withdrawn subsequent to the court's ruling and subsequent to a denial by the court of appeals of a motion to stay the preliminary injunction. 499 F.2d 467 (D.C. Cir. 1974). See also note 35 supra.
} 
that Iowa was again able to enforce its laws and to continue developing its safety program. Iowa's administration of occupational safety and health programs has had as dramatic an impact as that in Washington. The response and results achieved in Iowa show what a smaller state can do if it exercises all the opportunities extended to a state under the federal Act.

\section{The Michigan State Program Versus the Federal Program in Ohio}

A comparison might be helpful in illustrating the positive elements in state plans. Unlike Michigan, Ohio has never chosen to enter a state plan under section 18(b). Michigan's governor has been an enthusiastic supporter of state programs. Ohio has four federal area offices in major cities and those offices occasionally borrow compliance officers from Michigan and other neighboring states to handle compliance matters. The number of compliance officers in Ohio in 1971 and 1972 never exceeded 30, though recent transfers and hires have more than doubled this number. In Michigan the state agencies have had almost 100 health, construction, and general job safety inspectors in the field since $1970 .{ }^{40}$ There have also been approximately a dozen federal officers based in Detroit to serve the entire state. Though somewhat smaller in worker population than Ohio and somewhat less industrialized because of its larger rural area in the north, Michigan has thus had more than three times the number of compliance officers regularly inspecting workplaces.

In recruiting these inspectors, Michigan has a strong attraction for its own qualified citizens because they often need not relocate. These local inspectors possess knowledge of local conditions and problems as well as practical job experience. Many also have roots in the local labor movement or industry. Michigan's qualifications for an entrance job in safety inspection places great emphasis on actual job experience, in addition to academic achievement and test scores. This approach is designed to encourage qualified applications from those who have been active in the occupational safety and health movement within organized labor or management, from minority groups, and from qualified women.

In addition to knowledgeable local inspectors, a state plan offers community leaders the opportunity to participate in a program meaningful to their constituents. Under Michigan's state plan, both labor and management have a much greater role, legally and practically, in the rulemaking and policy-making aspects of the program than they do at the federal level. Indeed, some of Michigan's state standards should achieve greater effectiveness than federal standards because of the contributions of the tripartite industry committees which have edited, clarified, and enlarged federal standards, while maintaining "as effective as" basic requirements. Michigan's reporting and statistical program is also more comprehensive than the federal program.

Another advantage of state programs is the potential for alternative approaches for achieving compliance provided by other state laws, such as work-

\footnotetext{
${ }^{40}$ See Michigan Dep't of Labor, 1973 annual Report 72, 80 (1974); Michigan Dep't of
} Public Health, 1974 Program Plan 241, 247 (1974). 
men's compensation benefit penalties or the prohibition of the employment of minors when an employer's operation is shown to be unsafe. A high accident rate could also result in an increase in inspections by the state as a further deterrent to unsafe conditions. No such program currently exists under OSHA. A greater emphasis on safety education and training in the state program will help workers and management become more conscious of their rights and duties under the law. These approaches can all provide a more effective means of achieving safety than OSHA has yet provided.

While international union spokesmen currently oppose all state plans, ${ }^{41}$ initially they indicated the elements of a state plan which had to be present before organized labor could give its encouragement to a state plan or legislation. Those requirements were (1) worker participation in a body comparable to the national advisory committee, (2) employee observation of monitoring exposure to toxic materials, (3) protection for complainants whose names would be withheld from employers upon request, (4) prohibition against advance notice of the inspection, (5) the right of employees or their representatives to accompany inspectors during their "walk around," (6) written inspection reports following the compliance officer's tour, and (7) placing these health and safety responsibilities in a state agency whose other functions do not conflict with the protection of workers.

Michigan's state plan will meet all these criteria. The legislation passed by the Michigan legislature in May, 1974, will provide more than $\$ 4$ million to support nearly 200 field personnel in one of the nation's most ambitious job safety and health programs. Some of the innovations in inspection scheduling, employer training programs, and health hazard abatement programs might never have been instituted had not this state program been implemented.

\section{IV}

\section{Innovations and Problems}

\section{A. State Program Innovations}

While most state legislation mirrors the federal law, the federal government has wisely allowed some room for innovation in each of the plans it has approved. It should be obvious that what is a necessary and proper occupational safety or health standard for Florida may be an inappropriate and weak standard for Michigan. National standards often represent a floor or common denominator that is less than what we should settle for in a northern, industrial and/or highly unionized state. Even though the Act calls for only an equivalency in effectiveness for a state plan, the citizens in individual states may demand something more in certain safety and health areas. Under state plans, the individual states are free to improve upon standards promulgated by OSHA in order to maximize workplace safety and health. Some states are in the process of promulgating more effective standards now.

In some states a degree of controlled consultation is allowed, though it is

\footnotetext{
${ }^{11}$ See note 4 supra.
} 
largely prohibited for federal personnel. Advisory committees also play a far more important role in standards promulgation in some jurisdictions than at the federal level. Often a greater emphasis on training, education, and attitudinal changes is provided by the states than one finds in the federal scheme.

Other states have used techniques to establish the priority for inspections different from the federal government's "target industries" and "target health hazards" approach. In addition, some states have created specialists within their inspection forces so that some inspectors inspect construction projects, others conduct general industry inspections, and still others inspect for occupational health purposes. These innovations, combined with the modern and uniform reporting techniques instituted under OSHA, will for the first time allow a basis for comparison as to how best our nation can eliminate hazards and reduce accidents on the job.

\section{B. Outstanding Problems in State Administration}

Some states remain weak in the field of industrial hygiene. A few are fortunate in having an aggressive and modern state health department with an admirable record of concern for occupational safety and health. One outstanding example is New York, where the whole occupational health administration is effectively merged with the state department of labor. But in many states the health department still is struggling to develop adequate competence in administering and enforcing an occupational health program. Often small state departments of health do not have the time or strength to involve themselves in job health matters. The federal government must do as much as it can to encourage a prompt and adequate growth of state health inspection capabilities.

A second outstanding problem is that of differing state standards. Large employers and international unions desire absolute uniformity between federal and state standards. They argue that if a state wishes to administer its own safety program, it should be able to do so effectively by simply adopting the federal standards. Employers fear some state standards may be too strict, while unions fear they may be too weak. If only federal standards exist, an employer can move men, equipment, and operations from one state to another without modifying its procedures or retraining its employees. More importantly for the small operator, analyses of recent federal variances ${ }^{42}$ or appeal decisions by the Review Commission ${ }^{43}$ (analyzed in national services and periodicals) will have considerable influence on state determinations.

Thus far, only four states-California, Michigan, New York, and Washington-have independently created standards. In many instances these state standards are so close to the federal standards that only an expert can detect the differences. In other cases, such as in California, the state standards are performance oriented, in contrast to the federal specifications. Though the result

\footnotetext{
${ }^{42}$ See Occ. Safety \& Health Act $\S \S 6(\mathrm{~b})(6)(A), 6(d), 29$ U.S.C. $\S \S 655(\mathrm{~b})(6)(A), 655(d)$ (1970).

43 Citations are issued by the Department of Labor for violations of standards or for violations of section $5(\mathrm{a})(1)$ of the Act, the general duty clause. Id. $\$ 5(\mathrm{a})(1), 29$ U.S.C. $\$ 654(\mathrm{a})(1)$. These citations may be appealed to the independent Occupational Safety and Health Review Commission, which was established pursuant to section 12 . Id. $\S 12,29$ U.S.C. $\$ 661$.
} 
may be the same, it takes an engineer to understand the differences and the similarities for job applications. In Michigan some standards are identical and some are quite different. When only the state has enforcement jurisdiction, the significance of such differences diminishes. There will be, however, growing pressures in the years ahead for national uniformity in standards.

Related to the problem of uniform standards is the question of variances and appeals decisions. If a national system of uniform standards is established, then the state variances from those standards and state interpretive decisions based upon those standards should be reciprocal with the federal determinations. Perhaps states should simply be bound by federal interpretations of such standards. In any event, pockets of loose enforcement and soft interpretation must be searched out and eliminated or one state could develop a reputation for "over-friendliness" to employers in much the same way that Nevada became a divorce haven and Delaware became a corporation "home office" in past years.

The quality of inspections between the states must also be uniform. States must abandon their practice of making safety inspectors political appointments. Federal entrance requirements must be met or exceeded whenever possible, and inspectors must be trained in a way that will make them true professionals. Instances of proven bribery or incompetence must be disciplined promptly and severely. Federal monitoring must be rigid to help assure uniform application.

Finally, there may be a major problem in many states in obtaining passage of the necessary enabling legislation. Currently, legislation has been defeated, bottled up in committee, or delayed on the calendar in Missouri, New Jersey, New York, and a number of other states. ${ }^{44}$ Often labor or management attempts to achieve major variations in state legislation. Unions desire stronger enforcement schemes that those set forth in the federal Act, which is already regarded as one of the strongest regulatory laws ever conceived concerning employment conditions. Businessmen attempt to erode employee rights, posting requirements, and the first-instance sanctions, which were devised by Congress to motivate employers to act before the inspector arrives. Any extreme variations from the federal law in state legislation will keep the state plan from achieving OSHA approval. There is a strong possibility that legislation enacted in Virginia and the District of Columbia may be deemed inadequate.

\section{V}

\section{Outlook on Federal Involvement}

The federal government's request for fiscal year 1975 state plan operational grants is $\$ 46$ million for the first 26 state plans it has approved. This is an increase of over $\$ 23$ million from the fiscal year 1974 budget. It had not yet approved funds for 20 other jurisdictions whose plans are pending. It is anticipated that approximately 30 states will be in the approved plan category in 1975 which would result in matching grants of nearly $\$ 46$ million for the third year of the program. The inclusion of program grants for large industrial states

\footnotetext{
143 Occ. Safety \& Health ReP. 849-50 (1973).
} 
such as Florida, Massachusetts, and Texas would have an especially dramatic impact on funding. When all the states' plans that eventually will be approved are included, nearly $\$ 100$ million in state matching funds will be supporting OSHA programs. It is a kind of reverse revenue sharing. Many observers believe it also demonstrates the degree of commitment by states during a period of taxpayer revolution and increased demands for other programs, such as environmental protection.

The total federal budget request for the Department of Labor's occupational safety and health program is approximately $\$ 102$ million. There have been some efforts in Congress to reduce this amount or to put more money into state grants rather than into federal operational programs. However, many members of the Senate will support efforts to increase OSHA enforcement and NIOSH budgets considerably. The current budget would authorize 920 compliance officers and industrial hygienists, and it would bring about a projected annual total of 105,000 inspections. Through the program of grants for the states, it is estimated that nearly 2,000 more state inspectors will be added if the job safety and health programs now pending before the Department of Labor are adopted. ${ }^{45}$ Most veteran observers believe that the most that can be expected in congressional funding under the Act in 1974-75 is the status quo, with some marginal improvements in the public sector. Such predictions are made on the basis of testimony before this Congress regarding effects of the Act on farmers and small employers.

\section{Conclusion}

Does a tough regulatory piece of legislation like OSHA actually reduce the number of industrial accidents that occur? The recent report by Mr. Jones of Ontario ${ }^{46}$ and the study done by the Wisconsin Department of Labor for $\mathrm{OSHA}^{47}$ suggest that the standards and regulations can only reduce or prevent about half of the industrial accidents that occur. $\boldsymbol{A}$ healthful, sanitary, welllighted, completely protected workplace may still be the locus of many severe and disabling accidents. Attitudes, behavior patterns, horseplay, preexisting physical conditions, and employee activities outside the workplace may still be predominant causal factors in accidents.

While we may not be able to prevent or eliminate all occupational injuries, deaths, and diseases, active programs can contribute much in an effort to curtail the unnecessary human suffering and losses caused by workplace accidents. Successful programs will also decrease the economic costs in lost work time and workmen's compensation benefits which are a result of occupational injuries and diseases. In order to acheive such beneficial results a cooperative effort is essential among employers, employees, and government agencies. Governmental cooperation is essential at all levels, but especially between state and federal

\footnotetext{
45 See id. at 1131, for reported budget figures.

16 See D. Jones, Occupational SafeTy Programs - Are They Worth IT? (Report to the Labor Safety Council of Ontario, 1973).

${ }^{47}$ See Wisconsin State Dep't of Labok, of Industries, and Human Relations, INSPECTION EFFectiveness REPORT (1971).
} 
governments. Rather than becoming bogged down in intergovernmental bickering, all must concentrate their respective resources on the problem. Ultimately this is the only way that government can make a significant contribution in this area, with the greatest success to come from the states' implementation of the program. 


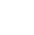

